\title{
Statistical Capacity Building of Official Statisticians in Practice: Case of the Consumer Price Index
}

\author{
Tomi Deutsch ${ }^{1}$
}

\begin{abstract}
This article focuses on the issue of statistical capacity building of official statisticians using the case of the consumer price index (CPI) as an illustrative example. Although used for indexation of salaries, pensions, and social welfare benefits, but also as an approximation of the general inflation rate, there are several unresolved methodological issues associated with CPI's calculation. Apart from the choice among two alternative concepts, the challenge of how to include owner-occupied housing $(\mathrm{OOH})$ in $\mathrm{CPI}$ has also not been adequately resolved yet. Analysis in the article is based on Slovenian data. The results show that accuracy of the CPI significantly improves if it is calculated using one of the superlative and symmetric formulas, and that it makes sense to include $\mathrm{OOH}$ in $\mathrm{CPI}$ using the total acquisitions approach. The analysis further indicates that the choice of the index formula for calculating CPI has a much greater impact on the CPI value than inclusion of $\mathrm{OOH}$. Academic research findings such as these should not remain unknown to the wide professional community of official statisticians. Formal channels for knowledge transfer from academia to official statistics providers should be established to facilitate continuous statistical capacity building of official statisticians.
\end{abstract}

Key words: Statistical capacity building; consumer price index; superlative index formulas; owner-occupied housing; total acquisitions approach.

\section{Introduction}

The World Bank (2016) defines statistical capacity as "the ability of countries to meet user needs for good quality statistics". Usually, the statistics this definition refers to are those we tend to label 'official': produced by national and international statistics providers to help local, regional, and national governments, as well as unions of countries, make informed policy decisions and monitor their impact.

Following from the definition of statistical capacity, statistical capacity building can be defined as all efforts and activities towards raising the ability of countries to meet user needs for good quality statistics, or, put more simply, to establish a statistical system capable of providing users with timely and reliable official statistics.

The statistical capacity building activities of the United Nations, the World Bank, International Statistical Institute and its Committee on Statistical Capacity Building, and many other organizations, are usually focused on training of official statisticians in developing countries. However, even in countries with well-established statistical systems, statistical capacity building should be an ongoing process. Dilemmas of official

${ }^{1}$ University of Ljubljana, Faculty of Economics, Kardeljeva ploščad 17, 1000 Ljubljana, Slovenia. Email: tomi.deutsch@ef.uni-lj.si 
statisticians in developed countries might be different, but they are by no means less numerous than dilemmas faced by their colleagues from developing countries.

This article focuses on the issue of statistical capacity building of official statisticians in practice, using the case of the consumer price index (CPI) as an illustrative example. Although utilized for indexation of salaries, pensions, and social welfare benefits, but also as an approximation of the general inflation rate, there are presently several unresolved methodological issues associated with the calculation of this indicator. Apart from the choice among two alternative concepts, the challenge of how to include owner-occupied housing $(\mathrm{OOH})$ in CPI has also not been adequately resolved yet. Two important CPIrelated methodological questions are therefore addressed in this article:

1. Do any of the existing index formulas help to significantly improve the accuracy of CPI?

2. Which among the available approaches to inclusion of $\mathrm{OOH}$ in $\mathrm{CPI}$ should be used in practice?

Following the introduction, we first provide an overview of formulas available for CPI calculations. We then discuss the pros and cons of existing approaches for inclusion of $\mathrm{OOH}$ in CPI. After establishing the theoretical framework we put theory to practice using Slovenia, a small open economy with a register-based system of official statistics, as a showcase. A discussion of possibilities to systematically disseminate academic research findings in the field of official statistics among the wide professional community of official statisticians concludes the article.

\section{Formulas Available for CPI Calculations: An Overview}

When deciding how to approach the CPI calculations, official statisticians face the choice between two alternative concepts: the fixed basket concept and the cost of living concept (ILO 2004). In practice, both concepts usually yield a different final CPI value, although convergences are possible (and feasible).

Availability of adequate weights (or quantities of goods) makes use of formulas for weighted price indices in CPI calculations possible. The choice among several alternatives depicted in Table 1 largely depends on the adopted concept and data availability required by the specific index formula.

According to the fixed basket concept, the CPI is calculated using a formula in which weights remain fixed and do not change between the compared periods. There are several options for choosing weights. By selecting the weights from one of the two compared periods, that is, the base or the current period, the Laspeyres $\left(\mathrm{P}_{\mathrm{L}}\right)$, or the Paasche price index $\left(\mathrm{P}_{\mathrm{P}}\right)$ is obtained.

The Laspeyres price index is calculated using the weights from the base period of prices, independent of the structure of population consumption in the current period. Assuming that changes in consumption are largely caused by replacement of relatively expensive goods with relatively cheaper ones, this index yields values which overestimate actual price movements between two periods.

The Paasche price index is calculated by taking into account the structure of consumption in the current period. Assuming that changes in consumption are largely 
Table 1. Alternative index formulas used in CPI calculations.

\begin{tabular}{|c|c|c|}
\hline Description & $\begin{array}{l}\text { Weights } \\
\text { reference } \\
\text { period }\end{array}$ & Index formula \\
\hline \multirow[t]{2}{*}{$\begin{array}{l}\text { Fixed basket index } \\
\text { (Target index) }\end{array}$} & $t=1$ & $P_{P}=\frac{\sum_{i=1}^{n} p_{i}^{t} q_{i}^{t}}{\sum_{i=1}^{n} p_{i}^{0} q_{i}^{t}}=\left\{\sum_{i=1}^{n}\left(\frac{p_{i}^{t}}{p_{i}^{0}}\right)^{-1} s_{i}^{t}\right\}^{-1} ; s_{i}^{t}=\frac{p_{i}^{t} q_{i}^{t}}{\sum_{i=1}^{n} p_{i}^{t} q_{i}^{t}}$ \\
\hline & $t=0$ & $P_{L}=\frac{\sum_{i=1}^{n} p_{i}^{t} q_{i}^{0}}{\sum_{i=1}^{n} p_{i}^{0} q_{i}^{0}}=\sum_{i=1}^{n} \frac{p_{i}^{t}}{p_{i}^{0}} s_{i}^{0} ; s_{i}^{0}=\frac{p_{i}^{0} q_{i}^{0}}{\sum_{i=1}^{n} p_{i}^{0} q_{i}^{0}}$ \\
\hline $\begin{array}{l}\text { Cost of living index } \\
\text { (Target index) }\end{array}$ & $t=1, t=0$ & $P_{F}=\sqrt{P_{L} P_{P}}$ \\
\hline $\begin{array}{l}\text { Fixed basket index } \\
\text { (Approximation) }\end{array}$ & $t \leq-1$ & $\begin{array}{l}P_{L o}=\frac{\sum_{i=1}^{n} p_{i}^{t} q_{i}^{b}}{\sum_{i=1}^{n} p_{i}^{0} q_{i}^{b}}=\sum_{i=1}^{n} \frac{p_{i}^{t}}{p_{i}^{0}} s_{i}^{0 b} ; s_{i}^{0 b}=\frac{p_{i}^{0} q_{i}^{b}}{\sum_{i=1}^{n} p_{i}^{0} q_{i}^{b}} \\
P_{Y o}=\sum_{i=1}^{n} \frac{p_{i}^{t}}{p_{i}^{0}} s_{i}^{b} ; s_{i}^{b}=\frac{p_{i}^{b} q_{i}^{b}}{\sum_{i=1}^{n} p_{i}^{b} q_{i}^{b}}\end{array}$ \\
\hline \multirow[t]{2}{*}{$\begin{array}{l}\text { Cost of living index } \\
\text { (Approximation) }\end{array}$} & $t=0$ & $P_{G L}=\prod_{i=1}^{n}\left(\frac{p_{i}^{t}}{p_{i}^{0}}\right)^{s_{i}^{0}} ; s_{i}^{0}=\frac{p_{i}^{0} q_{i}^{0}}{\sum_{i=1}^{n} p_{i}^{0} q_{i}^{0}}$ \\
\hline & $t \leq-1$ & $P_{G Y o}=\prod_{i=1}^{n}\left(\frac{p_{i}^{t}}{p_{i}^{0}}\right)^{S_{i}^{o}} ; s_{i}^{b}=\frac{p_{i}^{b} q_{i}^{b}}{\sum_{i=1}^{n} p_{i}^{b} q_{i}^{b}}$ \\
\hline
\end{tabular}

Source: ILO, 2004.

caused by replacement of relatively expensive goods with relatively cheaper ones, this index yields values that underestimate the actual movement of prices between two periods.

From the theoretical viewpoint, it is impossible to determine which index formula, the Laspeyres or the Paasche one, is more suitable for CPI calculations. While both seem equally probable, they generally give different answers to the same question (ILO 2004, par. 15.17). For practical reasons, the Laspeyres index formula has been more frequently used in practice, because the weights from the base period are relatively easily obtainable in comparison to the weights from the current period.

Neither the Laspeyres nor the Paasche price index is suitable for measurement of inflation faced by households. An established inflation rate should not have a probable alternative value and should account for the structure of the household consumption in both the base and the current period. Diewert (1999, 31-32) reports that Walsh therefore (already in 1921) suggested to combine both indices.

Combining the quantities from both periods with the arithmetic mean formula results in the so-called Marshall-Edgeworth index. This index is rather problematic in international comparisons and therefore rarely used.

Combining the quantities from both periods with the geometric mean formula yields the Walsh price index. This index, together with the Törnqvist-Theil (or equivalent Törnqvist) and Fisher price index $\left(\mathrm{P}_{\mathrm{F}}\right)$, forms a group of symmetric and superlative formulas which under certain assumptions (constant utility function over time, homothetic preferences see Breuer 2007, 3) represent a good approximation of the real cost of living index (Diewert 1976). 
The weights in the Walsh index are calculated as a combination of weights from the base and the current period and are fixed. Consequently, this index reflects price changes only. This characterizes it as an unbiased pure price index (Hill 1999, 10).

For the normal time series of data, Fisher, Törnqvist-Theil, and Walsh indices are only approximately consistent in aggregation (ILO 2004, par. 6.17), but yield similar values. Consequently, it does not matter which of these three index formulas are chosen as the target index for the CPI (ILO 2004, par. 17.5). With the Walsh index formula declared suitable for the fixed basket concept, and given the negligible differences between superlative formulas, we can assume that the other two remaining superlative formulas, that is, Fisher and Törnqvist-Theil, are also suitable for CPI calculations according to the fixed basket concept. This has been proven by Diewert $(2002,590)$. He also showed that among these three, the Fisher formula yields the best results both in terms of the economic and test approach (Diewert, 1999, pp. 7 and 18).

When calculating CPI in real time according to the concept of the fixed basket, it makes sense to use one of the alternative formulas which result in an approximation of the Laspeyres index. The most appropriate and most commonly used in practice are the Young index $\left(\mathrm{P}_{\mathrm{Yo}}\right)$ and the Lowe index with hybrid weights $\left(\mathrm{P}_{\mathrm{LO}}\right)$. The Young index uses available weights from the period prior to the base period. If we multiply weights used for the calculation of the Young index with the base period prices, we obtain the Lowe index with hybrid weights (but have to take into account issues related to the elasticity of substitution - see UN 2009, par. 4.83).

Given that superlative indices also cover substitution between goods, geometric formulas assuming this substitution can be used. Such CPI approximations are calculated using the geometric forms of the Young $\left(\mathrm{P}_{\mathrm{GYo}}\right)$ and/or Laspeyres $\left(\mathrm{P}_{\mathrm{GL}}\right)$ index. These require the same data as their arithmetic equivalents (Armknecht and Silver 2012, 4; ILO 2004, par. 1.40). However, due to the delayed availability of weights, only the geometric Young index can be calculated without any major problems in real time.

Practical limitations to the use of these two indices include avoidance of prices that are equal to zero. Attention should be paid to the significant drops in prices. Elasticity of substitution is an issue as well: Armknecht and Silver $(2012,4)$ note that the geometric Young index is biased downwards when inelastic substitution is present. Similar bias can also be expected when the geometric Laspeyres index is used.

\section{Approaches for Inclusion of the Owner-Occupied Housing in Consumer Price Index: An Overview}

Five possible approaches for inclusion of $\mathrm{OOH}$ in $\mathrm{CPI}$ are reviewed next:

- the user cost approach,

- the rental equivalence approach,

- the payments approach,

- the net acquisitions approach,

- the total acquisitions approach.

The review helps us round the theoretical framework for the subsequent empirical showcase. 


\subsection{The User Cost Approach}

This approach builds on the cost of living concept which means that it considers the cost incurred by the use of durable goods instead of their prices (Diewert 2003, 3; UN 2009, par. 9.1.9). Consequently, according to ILO (ILO 2004, par. 10.8) we attempt to measure changes in the cost to owner-occupiers for using the dwelling. ILO (ILO 2004, par. 10.10) also provides a typical formula for the estimation of user costs: $U C=r M+i E+D+R C-K$.

The equation for the calculation of user costs (UC) can be interpreted as the difference between the cost of the acquisition of housing, later use of the housing and selling of the housing at the end of the period (Spiteri 2008, 52): $M$ and $E$ represent mortgage debt and equity in the home, and $r$ and $i$ represent mortgage interest rates and the rate of return available on alternative assets, respectively. $D$ is depreciation, $R C$ other recurring costs and capital gains $K$ (with a negative prefix).

The user costs approach has a number of theoretical and practical issues which do not make it popular among statisticians (Kurz and Hoffmann 2004, 3). Two of the most pressing ones include:

- Reduced consistency of CPI: the user cost approach should be applied to all durable goods (i.e., all goods used longer than one month). In reality, the approach is only used for $\mathrm{OOH}$ inclusion.

- User costs cannot be calculated only on the basis of actually observed data (irrespective of the degree of difficulty in data collection processes). Certain parameters also need to be estimated and imputed. However, simplified forms of user costs approach are used in practice, even though they do not eliminate the problems of setting the parameter values (Guðnason and Jónsdóttir 2008).

\subsection{The Rental Equivalence Approach}

As a consequence of the user cost approach weaknesses, the rental equivalence approach was developed. Apart from its perceived simplicity in comparison with the user cost approach, its main advantage lies in its connection to both the cost of living and the fixed basket concepts.

The rental equivalence approach attempts to measure changes in the prices of housing services consumed by users of $\mathrm{OOH}$ by estimating the market value of these services or by estimating how much users would have to pay to rent their own housing (ILO 2004, par. 10.14). Imputed rents for $\mathrm{OOH}$ are equivalents of actual rents, which, besides the payment for the rent of the building or part of the building, also include the rent for the associated land. The amount of the imputed rent - as in actual rents - thus depends on the physical characteristics and the location of $\mathrm{OOH}$.

Certain requirements need to be fulfilled in order to use this approach (Spiteri 2008, 53):

- there is a market for rented dwellings and a significant amount of rented dwellings with characteristics similar to those of owner-occupied dwellings,

- the rental market is competitive and not heavily regulated,

- rented and owner-occupied housing are not subject to different tax regimes,

- rental statistics do not include services like electricity and insurance, but represent pure rental cost. 
Further, measured rent that was actually paid may deviate from the pure rental value due to potential inclusion of running maintenance costs of housing in the rent, equipment of rental housing and other reasons (Baldwin et al. 2006, 15).

The rental equivalence approach assumes that the rental housing services and $\mathrm{OOH}$ are perfect substitutes, but a number of countries have in the past experienced rapid growth in housing prices that was accompanied by moderate growth in rents (Heath 2007, 6). This creates a gap between the estimate of the costs of maintaining a certain standard of living and the actual costs faced by the households in order to provide for this standard. Consequently, it results in a biased CPI.

\subsection{The Payments Approach}

According to the payments approach, besides the real prices of housing (and other incurred costs), interest payments for the mortgage loans are also included in the CPI. The average mortgage debt is defined as the 'good', and the interest rate as its price (McCarthy 2007, 87). Consequently, the CPI includes the following housing expenditure (ILO 2004, par. 10.20):

- down payments or deposits on newly purchased dwellings,

- legal and real estate agency fees payable on property transfers,

- repayments of mortgage principal,

- mortgage interest payments,

- alterations and additions to the dwelling,

- insurance of the dwelling,

- repair and maintenance of the dwelling,

- property rates and taxes.

A great advantage of the payments approach in comparison to the user costs approach is that the index includes only those categories that can be actually observed. However, it is difficult to collect all the necessary data, so in practice this approach is rather difficult to implement without giving estimates on certain values, and is therefore rarely used. The need to include a large amount of data will probably remain the biggest obstacle for the implementation of this method in the CPI calculations (UN 2009, par. 9.1.11).

\subsection{Net Acquisitions Approach}

This approach is based on the inclusion of the actually observed prices and quantities (volume of expenditure), with both the prices and the volume of expenditure for products and services in the CPI attributable to the period in which the acquisition occurred. Consequently, the CPI covers only new constructions and housing new to the household sector.

The costs related to the $\mathrm{OOH}$ acquisition according to the net acquisitions approach, include (ILO 2004, par. 10.40):

- net purchases of dwellings (i.e., purchases less sales by the reference population),

- direct construction of new dwellings,

- alterations and additions to existing dwellings, 
- legal and real estate agency fees payable on property transfers,

- repair and maintenance of dwellings,

- insurance of dwellings,

- property rates and taxes.

The net acquisitions approach sets limitations on the inclusion of $\mathrm{OOH}$ expenditure only for the purchase of housing, while the rest of the $\mathrm{OOH}$ expenditure according to the net approach is not affected (deviation occurs only if the associated land is treated separately). Net purchases of housing include (ILO 2004, par. 10.42):

- dwellings purchased from businesses (newly constructed dwellings, company houses, or rental dwellings),

- dwellings purchased or transferred from the government sector,

- any purchases, for owner-occupation, of rental dwellings from the reference population households.

If the CPI is prepared for a subpopulation, purchases of housing from other types of households are included in the net purchase of housing (ILO 2004, par. 10.42).

Determination of the net volume of expenditure, which according to the net acquisitions approach drops in the CPI, opens quite a few dilemmas:

- Definitions of new construction purchases and existing housing sold to the households by companies, local and national authorities as well as other organizations outside of the household sector are quite clear and unproblematic in terms of data collection. However, the mere inclusion of this range of housing sold from the standpoint of the net acquisitions approach is not satisfactory. If we want to operate with the net purchase value of the reference population, we need to deduct all sales by the households to the remaining sectors from the weights these housing purchases have. That means a certain shift in the data collection; CPI is calculated on data on purchases of goods by households, while this additionally requested information relates to the sales by households.

- Another difficulty arises because of the inclusion of the existing housing sold by the households from the reference population. This housing is excluded from the net approach, with the exception of housing that has been functioning as rental housing before the purchase. By the analogy with the logic of including former private rental housing, all housing new to the household sector, which will be rented out after the acquisition, has to be excluded from the CPI. Furthermore, according to the same logic, the value of housing, which was rented after the owner moved away, should be deducted from the value of housing new to the household sector. On the other hand, the CPI should include all housing that was rented, but became owner-occupied because the owner moved in without a transaction carried out on the market.

- A further dilemma is related to the status of purchasing housing through a real estate agent. According to the net acquisitions approach the CPI includes all purchases of existing housing, which occur through a real estate agent, which means the difference between the purchase price and the selling price, wherein this difference represents the service of a real estate agent to the buyer (UN 2009, par. 9.6.4). All taxes (VAT, sales tax, and other mandatory charges on transactions of existing 
housing among the reference households) must be treated similarly, given that taxes are an integral part of the CPI (they represents the difference between the expenditures and incomes of households). For successful inclusion of housing in the $\mathrm{CPI}$ according to the net acquisitions approach, data related to the transactions with the existing housing is needed. Apart from the list of transactions with housing and transaction prices, we also need to acquire data on the percentage of expenditure that falls to taxes, which is included in the official records, and data on the percentage of the expenditure that goes to the real estate agent, which is usually not shown in the official records. In practice therefore, deviations from the framework of the net acquisitions approach are likely to occur. The official records on the sales of residential properties also do not show the household type (irrespective of the role of the household in the transaction), which prevents the possibility of including purchases of existing housing that were sold to the reference subpopulation by other types of households or households outside the reference subpopulation. This limitation prevents the calculation of the subsidiary CPI according to the net acquisitions approach, which includes expenditure of reference households for $\mathrm{OOH}$, for more accurate indexations of various household incomes.

- Probably the largest difficulty with the implementation of the net acquisitions approach is the treatment of the land associated with the OOH. Given that land is an integral part of actual rents in the CPI, the net acquisitions approach excludes land associated with the $\mathrm{OOH}$. Arguments for excluding land prices are - similar to the user cost approach - based on the investment theory instead of the theory of consumption, disregarding the fact that the land prices will affect the cost of living in the same range as the cost of buildings (Cournède 2005, 7). In the areas where the housing prices will rise due to lack of building land or increased demand on housing because of the favourable location of the area (e.g., due to the increase of available jobs), households will be faced with a rise in housing prices, which will in no way be reflected in the values of the CPI. The exclusion of land from the CPI is simple only when land for construction is bought. For the land related to $\mathrm{OOH}$, the exclusion from the CPI could be carried out only by separating transaction price of the housing into the parts, which represent the value of the land and the value of the building. Such a division is neither realistic nor feasible without a certain error. Inability to separate land prices from the prices of buildings is a serious deficiency in the use of the net transactions approach (Johnson 2015, 121). Because of the difficulties with separating the land prices from the prices of buildings, alternative models of including land prices according to the net acquisitions approach are emerging. This path has also been chosen by Eurostat in the foreseen inclusion of $\mathrm{OOH}$ in the Harmonised Index of Consumer Prices (HICP) from 2018 onwards (Eurostat 2013b, 22).

- The net acquisitions approach is further criticized because of insufficient weighting of $\mathrm{OOH}$ in the CPI. The advantage that this approach has over other methods of including $\mathrm{OOH}$ in the $\mathrm{CPI}$ is thus nullified because $\mathrm{OOH}$ is not attributed with the weight it has in reality.

- Finally, the net acquisitions approach is also not satisfactory when measuring inflation, since inflation is not independent of price movements of the existing 
housing. The increase of the general price level also includes the increase in the prices of existing housing on the market. By increasing prices of existing housing, the ratio between money and existing housing changes; with the same amount of money less existing housing can be bought. In a situation like that, we cannot claim that inflation equals zero.

All these difficulties are extremely serious arguments against the use of the net acquisitions approach in practice.

\subsection{Total Acquisitions Approach}

The difficulties with the net acquisitions approach can be avoided by including all acquisitions or household purchases, regardless of who the seller is, in the CPI. The socalled total acquisitions approach can be applied to the housing as most important durable good as well as to other durable goods with secondary markets, without any significant changes in the process of the CPI preparation.

Although the sale of used goods in the CPI should be excluded because ". . . a higher turnover rate (number of transactions) gives a higher total expenditure" (ILO 2004, par. 3.127), exactly this increase in the expenditure of these goods in the CPI is the biggest practical advantage of this approach. The size of weights, which are based on all housing purchases, is in fact the best possible transmitter of the importance that housing has for the reference population. The increase in the volume of transactions with housing (irrespective of the type of transaction) means an increase in the importance of housing in household consumption, which is not inconsistent with the definition of the weights in the CPI. Underrepresented housing (and by this the main disadvantage of the acquisitions approach compared to the user costs approach and to the rental equivalence approach) is thereby nullified. Moreover, having the adequate size of the weights for $\mathrm{OOH}$, the weights according to the total acquisitions approach are determined on the basis of actual measurements, rather than on the basis of any imputations. According to the total acquisitions approach, the CPI includes all housing units, which in the observed period were purchased by the reference population, so this approach does not bring impracticable division of housing into those units which the index should cover, and those units which have to be eliminated. All difficulties with the separation of the prices of buildings from the prices of land are also eliminated, since the prices of land are also included in the CPI.

The inclusion of even the existing housing and the purchases of other second-hand goods is not in contrast with the international resolution on the CPI, which states that "the expenditure weights for second-hand goods should be based either on the net expenditure of the reference population on such goods, or the gross expenditure, depending on the purpose of the index" (ILO 2003, par. 31). The total acquisitions approach is thus consistent with the international resolution for the indexation purposes as well as for the measurement of inflation, yet, paradoxically, not recognized as a possible method for $\mathrm{OOH}$ inclusion. Nevertheless it resolves numerous methodological issues inherent to the other four approaches.

According to the total acquisitions approach, $\mathrm{OOH}$ can be included in the CPI in a relatively simple way. In the first step we use available data and calculate an $\mathrm{OOH}$ price index, which contains all purchases of housing by the reference households. This 
index is then assigned an adequate weight (which is the same as the volume of all housing purchases by these households) for inclusion in the total CPI. The household expenditures for $\mathrm{OOH}$, which are included in the CPI in the preparation of prices and weights process are:

- market purchases of housing together with the associated land,

- purchase of land for construction and direct construction of new housing,

- adaptions and extensions of existing housing along with the repair and maintenance,

- legal costs and the costs of real estate brokerage in housing transactions (these are at least partially included in the selling price of housing),

- housing insurance, property rates, and taxes.

Given that according to the total acquisitions approach the $\mathrm{OOH}$ price index includes the purchases of housing on behalf of the reference population (regardless of the type of use of this housing), the purchases of housing which may become rental housing in the future are also covered. Yet eventual transition of the acquired housing to rental housing is not problematic within the total acquisitions approach, which further speaks for its practical implementation.

Certain limitations in the total acquisitions approach are represented solely by the transactions with shares of housing which generally occur among members of households and in other specific circumstances. Since these transactions typically do not reflect the real market prices of housing, their inclusion in the CPI is not justified.

\section{Putting Theory to Practice: The Case of Slovenia}

Let us take a closer look at how the total acquisitions approach could be implemented in practice using the data from the Slovenian statistical system.

\subsection{Data Sources and Limitations}

Our analysis is based on microdata collected and edited by the Statistical Office of the Republic of Slovenia (SORS 2012a, 2012b) for the purposes of calculating the official CPI and HICP, and collected from the Real Estate Market Register regulated by the Surveying and Mapping Authority of the Republic of Slovenia (SMARS 2012). Annual data from the Household Budget Survey (HBS) and the average monthly retail prices of products and services calculated with the arithmetic mean (AM) and geometric mean (GM) formulas was also obtained from the SORS. SORS provided access to all data to the level of products and services for researching purposes. Data on carried out transactions for all types of housing was obtained from the Real Estate Market Register.

Data from the HBS was used for the preparation of annual weights. Annual average prices used in the analysis were calculated from the monthly average prices using the formula for unweighted arithmetic mean. 285 weights were obtained for the period from 2004 to 2011 and 285 average prices of products and services were obtained for the period from January 2006 to December 2011. The analysis included a smaller than usual (for CPI calculations) number of average prices of products and services in order to simplify the 
analysis and eliminate specific impacts on the results and because of certain limitations in the database obtained from the SORS.

Prior to the analysis, we eliminated average prices for the products and services with missing values, products and services unrecorded in the HBS (products and services that were not covered with an adequate weight), products and services with the same weight (in case of a larger number of products and services at one weight, one adequate representative for the elementary aggregate was selected for the analysis) as well as products and services where changes in data collection occurred in the period analysed. The fact that products and services without an adequate weight appear in the dataset is mainly due to the mismatch in the classification of products and services; Classification of Individual Consumption According to Purpose (COICOP) classification is not used in the average price database at the level of products and services.

SORS calculates the acquired average prices of products and services using the AM formula (input data for the CPI) and GM formula (input data for the HICP). Although this is an advantage that enables the analysis of the substitution at the elementary level, these data have several limitations. Regardless of the different methodology of calculating the average prices, their values in certain products and services do not differ. Of the 285 products and services, 16 per cent have the same value in both databases. Among the products and services with the same average price in both databases, there are a number of substitutes. Due to these data limitations, the analysis of the differences that occur because of substitutions at the elementary level is slightly curtailed.

Data obtained from the HBS is not optimal. The survey is troubled with quite a large nonresponse rate, which may somewhat distort the recorded consumption of households. In the 2012 survey of 7,002 households in the initial sample, response was only received from 3,663 households (a 46 per cent nonresponse rate). The survey and logbook together were filled out by 2,647 households (a 61 per cent nonresponse rate) (Vrabič Kek et al. 2014).

From 2009 to 2011 the response rate was slightly higher than in 2012, suggesting a decrease in willingness of households to participate in the survey. From 2009 to 2010 there were 6,288 households in the initial sample, and the survey was filled out by 3,924 (a 35 per cent nonresponse rate); the survey and the logbook together were filled out by 2,970 households (a 51 per cent nonresponse rate) (Vrabič Kek et al. 2014).

The annual data from the HBS is based on the responses of about 1,300 households. A rather low response rate in the Slovenian HBS is not an exception. Other countries are also facing similar or even lower response rates (Tršelič Selan 2006, 33) with a detectable trend towards an increasing nonresponse rate (Johnson 2015, 18). In the future we cannot realistically expect to obtain better results only by improving methods of collecting the data by HBS. It is more likely that the trend of increasing nonresponse rate and thus inadequate coverage of household consumption will continue. Sooner or later statistical offices will be forced to replace the HBS with other, especially administrative sources.

Elementary CPI was updated with the data on housing transactions from the Real Estate Market Register for the period from January 2007 to December 2011. The Real Estate Market Register is the first and only systematic source of data for systematic monitoring of the contract prices of the real estate in Slovenia (Perovšek 2009) and as such the basis for other officially published data on the real estate prices in Slovenia. Given that this is a 
Table 2. Data on housing in apartment buildings.

\begin{tabular}{ccccc}
\hline Year & $\begin{array}{c}\text { Number of } \\
\text { transactions }\end{array}$ & $\begin{array}{c}\text { Contract price } \\
\text { (in EUR) }\end{array}$ & $\begin{array}{c}\text { Area } \\
\text { (in square meters) }\end{array}$ & $\begin{array}{c}\text { Price of square } \\
\text { meter (in EUR) }\end{array}$ \\
\hline 2007 & 6,557 & $82,467.2$ & 56.46 & $1,521.9$ \\
2008 & 5,231 & $96,932.1$ & 58.02 & $1,724.1$ \\
2009 & 4,662 & $88,615.4$ & 55.35 & $1,642.1$ \\
2010 & 7,116 & $88,480.7$ & 52.25 & $1,734.5$ \\
2011 & 7,242 & $85,329.9$ & 51.43 & $1,696.6$ \\
\hline
\end{tabular}

relatively recently created register, the quality of data is not optimal and stable yet (SMARS 2008 and 2013). For example, in the period relevant for our analysis, the reporting on new constructions was not reliable; we also needed to do some updating and/or cleaning of data on sales of new and existing houses which might have impacted our results.

Data cleaning eliminated only the transactions that are not adequate for further analysis. Setting limits on the value of the transaction or the size of the housing was done arbitrarily, but these limits were set in such a way as to only eliminate the extreme values, which more often than not indicated an input error or at least excessive specifics of these transactions. For housing in apartment buildings, all transactions for which the contract value was below EUR 5,000 or above EUR 500,000 were eliminated. When considering the size of housing, all transactions with housing that have area of less than 15 or more than 200 square meters were eliminated. The same goes for all transactions with the value per square meter below EUR 100. For houses, all transactions with the contract value below 5,000 or above EUR one million were eliminated. Finally, all transactions with a price less than EUR 100 per square meter or higher than EUR 9,500 were also eliminated.

After completion of data cleaning procedures, 30,808 transactions with housing in apartment buildings and 9,131 transactions with single-family houses that relate to the period from 2007 to 2011 remained in the database. Annual data on housing in apartment buildings are shown in Table 2 and on single-family houses in Table 3.

There are significant differences in all parameters shown between the housing in apartment buildings and single-family houses. For the main part they stem from different recording mode in the Real Estate Market Register: for single-family houses the net floor area of a building is entered and for housing in apartment buildings usable area of the building. The net floor area is the sum of all rooms and the usable area is the sum of all places for residing not including the technical and common areas (SMARS 2011).

Table 3. Data on single-family houses.

\begin{tabular}{ccccc}
\hline Year & $\begin{array}{c}\text { Number of } \\
\text { transactions }\end{array}$ & $\begin{array}{c}\text { Contract price } \\
\text { (in EUR) }\end{array}$ & $\begin{array}{c}\text { Area } \\
\text { (in square meters) }\end{array}$ & $\begin{array}{c}\text { Price of square } \\
\text { meter (in EUR) }\end{array}$ \\
\hline 2007 & 2,450 & $127,276.5$ & 127.01 & $1,088.1$ \\
2008 & 949 & $134,900.2$ & 133.56 & $1,143.4$ \\
2009 & 1,207 & $125,271.1$ & 135.43 & $1,028.2$ \\
2010 & 2,190 & $121,942.2$ & 141.47 & 936.9 \\
2011 & 2,335 & $120,024.3$ & 141.40 & 938.6 \\
\hline
\end{tabular}


Housing (new and used) is sold on the real estate market by different legal entities. In the period analysed there were 25,396 housing units in apartment buildings and 8,158 single-family houses sold on behalf of the households. Other legal entities in the period analysed sold 5,412 housing units in apartment buildings and 973 single-family houses. Among the housing in apartment buildings, 17.6 per cent was thus new to the household sector; for single-family houses this percentage amounts to 10.7 per cent.

Although new construction is slightly under-represented in the Real Estate Market Register, these initial difficulties in setting up the database probably did not significantly affect the share of transactions in which the seller comes from outside the household sector. A small number of these transactions are mainly the result of unsatisfactory renewal of the housing stock with new construction in Slovenia and a result of reduced sale of housing because of the onset of the economic crisis. The latter also significantly impacted the sale of existing housing in the analysed period.

\subsection{Weights and Formulas}

In our analysis, the annual average prices of goods and services are calculated on the basis of the monthly average prices provided by SORS, using the AM formula. The average housing prices, which are inputs into the $\mathrm{OOH}$ price index and the updated CPI, are calculated from data on the contractual values of housing transactions, also using the AM formula. The average prices per square meter are calculated from the individual values on an annual basis.

We base our analysis on the average prices per square meter and not the average prices of housing units as a whole. This approach guarantees a higher comparability of housing from different periods as it mostly eliminates the housing size impact.

The implemented stratification (the method recognized as one of the possibilities to control for changes in the quality of housing - see Eurostat 2013a) is carried out using characteristics such as age, number of rooms, and location. Two main strata (one for housing in apartment buildings and the other for single-family houses) are created and an average price per square meter of housing calculated for both.

Annual weights for $\mathrm{OOH}$ price index (for housing purchases) are calculated from the volume of housing transactions, with all transactions included in the calculation of the average prices also included in the calculation of the volume. Due to the preliminary data cleaning (and due to the assumption that new housing transactions are partially underrepresented), the weights are slightly underestimated. However, based on the assessment and review of all available data, it is safe to assume that this underestimation is not large. Weights for the remaining 285 products and services in the CPI as well as for major works and renovations are calculated from the HBS data.

The $\mathrm{OOH}$ price index itself is prepared in a slightly simplified version (for most of the analysis only focusing on the housing purchases). Other costs of households with owneroccupied housing are not covered due to the unavailability of sufficiently detailed data although their CPI inclusion is not problematic. However, it is also not essential for demonstrating the total acquisitions impact on the CPI value. The same goes for purchases of land for construction: the omission of this data does not significantly impact the results of the analysis either because the impact of the land price is already partially included in 
the $\mathrm{OOH}$ price index via the prices of new and existing houses with associated land. Finally, the impact of land for construction on the final value of the $\mathrm{OOH}$ price index and the CPI is, due to the relatively small weight for this land, correspondingly small.

In the next step, annual indices using the Laspeyres, Fisher and Young index formulas, along with the formulas for the Lowe index with updated weights and the geometric versions of the Young as well as the Laspeyres index were used. Despite the fact that superlative indices are consistent with the fixed basket concept, our analysis is mainly carried out as comparison between the cost of living index (using the Fisher price index formula) and the fixed basket index (using the Laspeyres price index formula).

\subsection{Calculation of the Basic Consumer Price Index}

Let us now take a look at how the use of formulas allows substitution to impact the CPI values.

We analyse the values of the Laspeyres index using the average prices calculated with the arithmetic and geometric mean formulas, and values of the Fisher index using the average prices that are calculated with the geometric mean formula. Table 4 shows the values of annual indices on the previous year for the period from 2006 to 2011, and the values of the annual chained indices in $2011(2005=100)$ in the last column of the table.

In the analysed period, the highest annual inflation was detected in 2008 and the lowest in 2010. The chained indices for the analysed period show an accumulation of a rather large difference; its minor part stems from alternative formulas used for calculation of the average prices, but most of it results from alternative weights used in different basic CPI formulas.

It follows from Table 4 that index which does not account for any kind of substitution has the highest value; it is followed by the index that takes into account the substitution at the level of goods (which is a lower level substitution) and the index which accounts both for substitution at the level of goods and substitution among goods.

The identified difference between two Laspeyres indices in Table 4 is probably slightly smaller than the actual difference would be, had we had more adequate data at our disposal (as already indicated, and contrary to expectations, some arithmetic and geometric averages for prices of goods in our two databases have the same value). Nevertheless, the results still indicate a large overestimation of inflation when the latter is calculated using formulas that do not consider substitution.

One of the theoretical arguments against calculating the CPI as a cost of living index using a superlative and symmetric index formula is that to calculate such an index, weights from both the base and the current period are needed. Therefore, it seems more appropriate

Table 4. Values of the basic CPI according to the use of different formulas.

\begin{tabular}{lcccccccc}
\hline & \multicolumn{6}{c}{ Previous year $=100$} & \multirow{2}{*}{$2005=100$} \\
\cline { 2 - 6 } \cline { 5 - 7 } Index formula & 2006 & 2007 & 2008 & 2009 & 2010 & 2011 & 2011 \\
\hline Laspeyres (AM) & 102.86 & 103.34 & 105.62 & 101.67 & 101.10 & 102.61 & 118.42 \\
Laspeyres (GM) & 102.76 & 103.24 & 105.46 & 101.56 & 100.67 & 102.51 & 117.26 \\
Fisher (GM) & 102.41 & 102.95 & 105.15 & 101.27 & 100.09 & 102.26 & 114.91 \\
\hline
\end{tabular}


to calculate the CPI as a fixed-basket index, for which only the weights from the base period are needed.

In practice, the limitations in weights will occur in calculation of both types of indices, because of the time lag which makes it impossible to calculate the CPI index with weights that would coincide in time with the base period. Therefore, the CPI as a fixed basket index is usually calculated with weights derived from the period prior to the base period. To avoid major divergence between the available data and the actual household consumption, in practice updating of weights is used, these price-updated expenditure weights should represent the household expenditure in the base period better.

According to the fixed-basket concept, the Laspeyres formula is most suitable for the CPI calculation. We already know that if weights from the period before the base period are available, the Young index formula can be used. When using the updated weights for the CPI calculation, the Lowe index formula with hybrid weights or the updated Lowe index is used. These indices are shown in Table 5 (all of them are based on average product prices calculated with the AM formula).

With the exception of 2007, differences between the annual Laspeyres and Young index are negligible, that is, less than 0.1 index points. Applying weights from the year prior to the base year, that is, from 2008 to 2011, does not significantly impact the annual CPI value calculated as a fixed-basket index. Updating the weights for this period is therefore unnecessary or moreover, as the results of our analysis show, the updating procedure even slightly reduces the accuracy of the annual CPI in 2008 and 2010. On the other hand, updating has proven to be quite appropriate in 2007, when the difference between the Young and the Laspeyres index is the highest.

Current values of the CPI as a cost of living index can be obtained using the formula for the geometric Young index. Using the formula for the geometric Laspeyres index we obtain CPI values with a certain time lag, but still faster than in case of the symmetric indices. This finding applies to the use of both geometric index formulas, as they can be calculated in the same time and with the same data as their more widely used arithmetic counterparts. All indices in Table 6 are based on average product prices calculated with the GM formula.

The geometric Laspeyres index values are quite close to the Fisher index. In the annual comparisons, difference between these two indices is typically up to 0.1 index points, with the exception of 2010 when there is a difference of 0.17 index points. Divergence between the annual Fisher and the geometric Young indices is slightly higher, especially in the period until 2008, when the difference approaches the value of 0.2 index points. When using the annual chained indices, the difference between geometric Young and Fisher

Table 5. Values of the basic CPI using outdated weights and target Laspeyres index.

\begin{tabular}{lcccccc}
\hline & \multicolumn{4}{c}{ Previous year $=100$} & & $2006=100$ \\
\cline { 2 - 5 } Index formula & 2007 & 2008 & 2009 & 2010 & 2011 & 2011 \\
\hline Young (AM) & 103.11 & 105.57 & 101.75 & 101.16 & 102.54 & 114.89 \\
U. Lowe (AM) & 103.32 & 105.69 & 101.60 & 100.97 & 102.66 & 115.01 \\
Laspeyres (AM) & 103.34 & 105.62 & 101.67 & 101.10 & 102.61 & 115.13 \\
\hline
\end{tabular}


Table 6. Values of the basic CPI using outdated weights and target Fisher index.

\begin{tabular}{|c|c|c|c|c|c|c|c|}
\hline \multirow[b]{2}{*}{ Index formula } & \multicolumn{6}{|c|}{ Previous year $=100$} & \multirow{2}{*}{$\frac{2005=100}{2011}$} \\
\hline & 2006 & 2007 & 2008 & 2009 & 2010 & 2011 & \\
\hline G. $\mathrm{Yo}_{\mathrm{O}}$ & 02.25 & 102.76 & 104.97 & 101. & 100.03 & 102 & 11 \\
\hline G. Laspeyres (GM) & 102.42 & 102.98 & 105.05 & 101.22 & 99.92 & 102 & 114.55 \\
\hline Fisher (GM) & 102.41 & 102.95 & 105.15 & 101.27 & 100.09 & 102.26 & 114.91 \\
\hline
\end{tabular}

indices amounts to 0.75 index points from 2005 to 2011 and the difference between the Fisher and geometric Laspeyres indices to 0.36 index points.

In comparison with the differences that occur in the final values of the CPI, the deviation is typically negligible - if it occurs - due to the use of weights from the period (year) before the base period. However, because from time to time, larger deviations can occur, all approximations to the target indices should be updated retrospectively.

By calculating the CPI according to the fixed basket concept, final values would be obtained with a one-year lag and by calculating the CPI according to the cost of living concept with a two-year lag. When using the cost of living concept, the value of the CPI could be checked in two steps - after one year by using the formula for the geometric Laspeyres index and after two years by using the formula for the Fisher index. A very similar correction is performed in the United States, where their chained CPI calculated as cost of living index is corrected twice (Bureau of Labor Statistics 2011). At the aggregate level they carry out the first and the second index calculation by using adjusted formulas for geometric mean. The third and final calculation is carried out by using the TörnqvistTheil index formula (Cage et al. 2003).

\subsection{Calculation of the Simplified Owner-Occupied Housing Price Index}

To adequately update the $\mathrm{CPI}$ with $\mathrm{OOH}$, in the first step we need to calculate the $\mathrm{OOH}$ price index. Due to unavailability of all data we simplify and reduce the $\mathrm{OOH}$ price index in our analysis to the housing purchases only. Consequently, the analysed CPI is composed solely of purchases of housing in apartment buildings and purchases of single-family houses. The weights for individual type of housing are shown in Table 7. We obtain them by calculating the share of individual type of housing in the overall sum of contract prices.

Since the contract prices for single-family houses are on average higher than those for housing in apartment buildings, the weight for this type of housing is larger than their share in the total number of transactions. In 2008, when in Slovenia the share of transactions with single-family houses fell to 15 per cent of all housing transactions, the

Table 7. Annual weights for individual type of housing in the OOH price index.

\begin{tabular}{llllll}
\hline & \multicolumn{5}{c}{ Year } \\
\cline { 2 - 5 } Type of housing & 2007 & 2008 & 2009 & 2010 & 2011 \\
\hline Housing in apartment buildings (\%) & 63.42 & 79.84 & 73.21 & 70.22 & 68.80 \\
Single-family houses (\%) & 36.58 & 20.16 & 26.79 & 29.78 & 31.20 \\
\hline
\end{tabular}


Table 8. Values of simplified $\mathrm{OOH}$ price index (housing purchases) using various index formulas.

\begin{tabular}{lccccc}
\hline & \multicolumn{3}{c}{ Previous year $=100$} & & $2007=100$ \\
\cline { 2 - 4 } Index formula & 2008 & 2009 & 2010 & 2011 & 2011 \\
\hline Laspeyres (AM) & 110.28 & 94.17 & 101.74 & 98.52 & 104.10 \\
Fisher (AM) & 110.90 & 93.96 & 101.30 & 98.53 & 104.00 \\
\hline
\end{tabular}

weight for single-family houses was still 20 per cent. After the normalization of the number of transactions in 2010 and 2011, the weight for single-family houses stabilized at about 30 per cent.

Indices presented in Table 8 are based on the average product prices calculated with the arithmetic mean formula.

Comparison shows no major differences between the values of both indices. Contrary to expectations, in 2008 a slightly higher growth in housing prices was recorded by the Fisher index. This is mainly due to the household behaviour - in this year the households mostly purchased housing in apartment buildings, prices of which were consequently increasing above average. A similar situation occurs again in 2011 (in this year households to a slightly larger extent purchased single-family houses, prices of which were consequently increasing above average), but in general the values of both indices are very similar and the differences between them negligible.

\subsection{Calculation of the Updated Consumer Price Index}

The updated CPI contains the $\mathrm{OOH}$ price index with the weight, which - due to simplifications described in the previous sections - represents only that part of the actual $\mathrm{OOH}$ price index, which relates to housing purchases.

The weight for the Slovenian housing purchases can be determined either from the HBS data or the Real Estate Market Register data (from the sum of all contracts). Although the data in the Real Estate Market Register is, as already stated, slightly condensed due to the database cleaning and due to the certain lack of coverage with new construction in the analysed period, the volume of housing transactions from this source is larger in all years than the volume that was recorded by the HBS. With the exception of 2008 and 2009, the differences are quite large. Since the Real Estate Market Register is an administrative source, we deem it much more relevant for the preparation of weights anyway. Consequently, the weights for the $\mathrm{OOH}$ price index in the CPI are prepared on the basis of this source. The weights for other goods in the updated CPI are calculated from the volume of expenditure on these goods in the HBS. Table 9 contains the time series of weights for the analysed period.

Apart from both crisis years 2008 and 2009, the weight for housing purchases in the CPI amounts to about six per cent. Although slightly underestimated for reasons already explained, we do not expect the size of this weight to significantly increase by total coverage of housing purchases. The potential inclusion of transactions with shares of housing might have a slightly larger impact on the weight size, yet does not stand to debate because typically, resales within households cannot be equated with transactions in the real estate market. 
Table 9. Annual weights for OOH price index (housing purchases) in the CPI.

\begin{tabular}{lrrrrr}
\hline & \multicolumn{5}{c}{ Year } \\
\cline { 2 - 6 } Description of expenditures & 2007 & 2008 & 2009 & 2010 & 2011 \\
\hline Other consumer goods (HBS) (\%) & 93.47 & 95.54 & 96.18 & 93.69 & 94.06 \\
Housing purchases (Real Estate Market & 6.53 & 4.46 & 3.82 & 6.31 & 5.94 \\
$\quad$ Register) (\%) & 100.00 & 100.00 & 100.00 & 100.00 & 100.00 \\
Total (\%) & & & & & \\
\hline
\end{tabular}

Annual weights for the $\mathrm{OOH}$ price index that also includes major works and renovations are shown in Table 10. For reasons of transparency, weights for major works and renovations are shown separately from the weights for the housing purchases, although both components belong in the $\mathrm{OOH}$ price index. Weights for major works and renovations are calculated from the volume of expenditure in the HBS. Weights that are shown do not cover other expenditures that fall within the $\mathrm{OOH}$ price index and the CPI (land for construction and other $\mathrm{OOH}$ costs) and other expenditures that are not included in the CPI.

The size of the weights for the $\mathrm{OOH}$ price index, which includes the housing purchases as well as major works and renovations, is only slightly larger than the weights which $\mathrm{OOH}$ has in the Slovenian national accounts (the size of weights for imputed rents). We can therefore conclude that the importance/relevance of $\mathrm{OOH}$ according to the total acquisitions approach is similar to the importance/relevance, which $\mathrm{OOH}$ would have, if we included the estimated costs of housing use (user costs or imputed rents) in the CPI. Implementation of the total acquisitions approach that includes transactions between households therefore does not cause inflation of weights for the $\mathrm{OOH}$.

Based on the calculated weights for the $\mathrm{OOH}$ price index in the CPI, update of the CPI is carried out. Values of the annual updated CPI are shown in Table 11, and the CPI was updated with the $\mathrm{OOH}$ price index which only includes the housing purchases (with average prices per square meter of housing calculated using the arithmetic mean formula).

At the annual level, the inclusion of the housing purchases in the CPI did not lead to major changes in the value of the CPI; there are no significant differences among the values of the updated annual indices and indices calculated only for the 285 products and services remaining in the database after data cleaning (compare with the basic CPI shown in Table 4). Values of the $\mathrm{OOH}$ price index were largely neutralized by an adequate

Table 10. Annual weights for $\mathrm{OOH}$ price index in the CPI (in percentages).

\begin{tabular}{lrrrrr}
\hline & \multicolumn{5}{c}{ Year } \\
\cline { 2 - 6 } Description of expenditures & 2007 & 2008 & 2009 & 2010 & 2011 \\
\hline $\begin{array}{l}\text { Other consumer goods (HBS) (\%) } \\
\begin{array}{l}\text { Major works and renovations } \\
\quad \text { (HBS) (\%) }\end{array}\end{array}$ & 87.01 & 88.46 & 88.29 & 86.73 & 88.05 \\
$\begin{array}{l}\text { Housing purchases (Real Estate Market } \\
\quad \text { Register) (\%) }\end{array}$ & 6.08 & 4.41 & 8.20 & 7.43 & 6.39 \\
\begin{tabular}{l} 
Total (\%) \\
\hline
\end{tabular} & 100.00 & 100.00 & 100.00 & 100.00 & 100.00 \\
\hline
\end{tabular}


Table 11. Annual updated CPI using various index formulas.

\begin{tabular}{lccccc}
\hline & \multicolumn{3}{c}{ Previous year $=100$} & & $2007=100$ \\
\cline { 2 - 4 } Index formula & 2008 & 2009 & 2010 & 2011 & 2011 \\
\hline Laspeyres (AM) & 105.83 & 101.39 & 101.14 & 102.36 & 111.09 \\
Laspeyres (GM) & 105.67 & 101.28 & 100.74 & 102.28 & 110.27 \\
Fisher (GM) & 105.40 & 100.99 & 100.16 & 102.04 & 108.80 \\
\hline
\end{tabular}

weighting of the index in the overall CPI. The impact of updating the CPI with the $\mathrm{OOH}$, compared to the impact that formula selection on a higher level and partially formula selection on the elementary level have on the value of the CPI, is almost negligible.

On the basis of our analysis we can therefore safely conclude that the use of the total acquisitions approach increases the validity of the CPI as an indicator of inflation while at the same time does not noticeably change the overall CPI.

\section{Conclusions}

Our main theoretical and empirical findings can be summarized as follows:

1. Accuracy of the CPI significantly improves if it is calculated using one of the superlative and symmetric formulas. For the fairly widespread fixed basket indices, which do not predict adjustment of consumption to market conditions, it has been shown that they overestimate the actual inflation faced by households.

2. It makes sense to include $\mathrm{OOH}$ in the CPI using the total acquisitions approach. With this approach the difficulties that are present in the currently established approaches of including $\mathrm{OOH}$ in the $\mathrm{CPI}$ are eliminated. Total acquisitions approach can be implemented in the CPI without major interventions in the calculation method and the structure of the CPI, since the differences to the currently applied approach of net acquisitions are minimal. Due to the consistency of the CPI, this approach, without any major difficulties, also applies to the purchases of other used products if they have a significant enough share in the total household consumption.

3. For those housing markets which are relatively small and subject to the influence of modest building cycles (that lead to quite uneven and unsatisfactory renewal of housing stock) the total acquisitions approach is the only possible way of including $\mathrm{OOH}$ in the CPI. The unproblematic nature of the total acquisitions approach's implementation in this specific case also indicates the possibility of its universal applicability in the CPI calculations.

4. Our analysis further indicates that the choice of the index formula for calculating CPI has a much greater impact on the CPI value than inclusion of $\mathrm{OOH}$.

These and similar academic research findings on indicators with such enormous economic and social policy implications as those inherent to the CPI should not remain unknown to the wide professional community of official statisticians. Formal channels for knowledge transfer from academia to official statistics providers should facilitate continuous statistical capacity building of official statisticians. 
Joint conferences organized by the likes of International Statistical Institute and its seven associations (one of which is the International Association for Official Statistics) are one established channel, scientific journals such as Statistical Journal of the IAOS and Journal of Official Statistics another. The third channel offers itself via the recently launched European Master in Official Statistics study programme, which promises not only statistical capacity building of official statisticians via formal pedagogical activities, but also by focused joint research efforts (formal and informal ones) of participating academic institutions and official statistics providers included in the European Statistical System and beyond.

\section{References}

Armknecht, P. and M. Silver. 2012. Post-Laspeyres: The Case for a New Formula for Compiling Consumer Price Indexes. IMF Working Paper, WP/12/105. Available at: https://www.imf.org/external/pubs/ft/wp/2012/wp12105.pdf. (accessed December 15, 2013).

Baldwin, A., M. Prud'homme, and A. Nakamura. 2006. An empirical analysis of the different concepts for owned accommodation in the Canadian CPI: the case of Ottawa, 1996 - 2005. Paris: Organisation for Economic Co-operation and Development.

Breuer, C.C. 2007. Cost-of-Living Indexes for Germany. Ottawa: 10th Ottawa Group Meeting.

Bureau of Labor Statistics. 2011. Consumer Price Index. Available at: http://www.bls. gov/cpi/superlink.htm (accessed April 3, 2014).

Cage, R., J.S. Greenlees, and P. Jackman. 2003. Introducing the Chained Consumer Price Index. Paris: Seventh meeting of the International Working Group on Price Indices. Available at: http://www.bls.gov/cpi/super_paris.pdf. (accessed March 23, 2011).

Cournède, B. 2005. House Prices and Inflation in the Euro Area: Economics Department Working Paper No. 450. Paris: Organisation for Economic Co-operation and Development. Doi: http://dx.doi.org/10.1787/037842735074

Diewert, W.E. 1976. "Exact and Superlative Index Numbers." Journal of Econometrics 4: 115-145. Doi: http://dx.doi.org/10.1016/0304-4076(76)90009-9

Diewert, W.E. 1999. The Consumer price index and index number purpose. Reykjavik: Fifth meeting of the International Working Group on Price Indices. Available at: http:// www.ottawagroup.org/Ottawa/ottawagroup.nsf/home/Meeting+5/\$file/1999\%205th $\%$ 20Meeting\%20-\%20Diewert\%20Erwin\%20-\%20The\%20Consumer\%20Price\% 20Index \%20and\%20Index\%20Number\%20Purpose \%202nd\%20Edition.pdf. (accessed March 30, 2010).

Diewert, W.E. 2002. "Harmonized Indexes of Consumer Prices: Their Conceptual Foundations." Zeitschrift für Volkswirtschaft und Statistik let. 138: 547-637.

Diewert, W.E. 2003. The Treatment of Owner Occupied Housing and Other Durables in a Consumer Price Index. Available at: http://webstat.stat.fi/og2004/diewertpaper.pdf (accessed February 19, 2008).

Eurostat. 2013a. Handbook on Residential Property Prices Indices (RPPIs). Luxembourg: Publications Office of the European Union. Doi: http://dx.doi.org/10.2785/34007 
Eurostat. 2013b. Methodological Manual Referred to in Commission Regulation (EU) No 93/2013. Luxembourg: Eurostat. Available at: http://ec.europa.eu/eurostat/documents/ 272892/272983/Methodological_manual_referred_in_Reg_93_2013.pdf/922f0abf339d-4215-9c88-16c502557b87. (accessed, July 30, 2015).

Guðnason, R. and G.R. Jónsdóttir. 2008. House Price Indexes, Approaches and Methods. Washington DC: The 2008 World Congress on National Accounts and Economic Performance Measures for Nations. Available at: https://hagstofa.is/media/49627/ house_prices_indexes_mai_2008.pdf. (accessed January 30, 2010).

Heath, A. 2007. CPI Measurement Issues with a Special Focus on Owner-Occupied Housing. Basel: Bank for International Settlements. Available at: http://www.nbrm.mk/ WBStorage/Files/Macedonia\%20paper_Alex\%20Heath0.pdf. (accessed February 19, 2008).

Hill, P. 1999. Inflation, the Cost of Living and the Domain of a Consumer Price Index. Joint UNECE/ILO Meeting on Consumer Price Indices. Available at: http://hdl.handle. net/11176/360226. (accessed January 14, 2010).

ILO. 2003. Resolution Concerning Consumer Price Indices. Geneva: International Labour Organization. Available at: http://www.ilo.org/public/english/bureau/stat/download/ res/cpi2.pdf. (accessed December 12, 2012).

ILO. 2004. Consumer Price Index Manual. Geneva: International Labour Organization. Available at: http://www.ilo.org/public/english/bureau/stat/guides/cpi/\#manual. (accessed December 12, 2012).

Johnson, P. 2015. UK Consumer Price Statistics: A Review. London: UK Statistics Authority. Available at: https://www.statisticsauthority.gov.uk/archive/ reports-correspondence/current-reviews/uk-consumer-price-statistics—a-review.pdf. (accessed September 22, 2015).

Kurz, C. and J. Hoffmann. 2004. A Rental-Equivalence Index for Owner-Occupied Housing in West Germany, 1985 to 1998. Vancouver: SSHRC International Conference on Index Number Theory and the Measurement of Prices and Productivity. Available at: https://www.bundesbank.de/Redaktion/EN/Downloads/Publications/

Discussion_Paper_1/2004/2004_03_18_dkp_08.pdf?__blob=publicationFile. (accessed February 19, 2008).

McCarthy, C. 2007. "Owner-Occupied Housing Costs and Bias in the Irish Consumer Price Index." Quarterly Economic Commentary, Autumn 2007: 83-98. Available at: https://www.esri.ie/publications/owner-occupied-housing-costs-and-bias-in-the-consumer-price-index/ (accessed February 26, 2008).

Perovšek, A. 2009. Evidenca Trga Nepremičnin (ETN): Prispevek za Sosvet SURS. Ljubljana: Surveying and Mapping Authority of the Republic of Slovenia.

SMARS. 2008. Poročilo o Slovenskem Trgu Nepremičnin za Leto 2007. Ljubljana: Surveying and Mapping Authority of the Republic of Slovenia. Available at: http:// e-prostor.gov.si/fileadmin/etn/POROCILO_2007_GESLO.pdf. (accessed March 24, 2015).

SMARS. 2011. Tehnična Navodila in Primeri za Izračun Površin Prostorov in Delov Stavb. Ljubljana: Surveying and Mapping Authority of the Republic of Slovenia. Available at: http://www.gu.gov.si/fileadmin/gu.gov.si/pageuploads/zakonodaja/ ZEN_am/Tehnicna_navodila_07_11_11.pdf. (accessed March 24, 2015). 
SMARS. 2012. Evidenca Trga Nepremičnin (Microdata). Ljubljana: Surveying and Mapping Authority of the Republic of Slovenia.

SMARS. 2013. Metodološka Pojasnila k Periodičnim Poročilom (Različica 3.1). Ljubljana: Surveying and Mapping Authority of the Republic of Slovenia. Available at: http://www.e-prostor.gov.si/fileadmin/etn/Porocila/Metodoloska_pojasnila_k_ periodicnim_porocilom_3_1.pdf. (accessed March 23, 2015).

SORS. 2012a. Anketa o Porabi v Gopodinjstvih, 2004 - 2011 (Microdata). Ljubljana: Statistical Office of the Republic of Slovenia.

SORS. 2012b. Povprečne Mesečne Cene, 2005 - 2011 (Microdata). Ljubljana: Statistical Office of the Republic of Slovenia.

Spiteri, A. 2008. "Owner-Occupied Housing and its Effect on the Measurement of Inflation for Malta." Bank of Valletta Review 38: 47-72. Available at: http://citeseerx. ist.psu.edu/viewdoc/download?doi=10.1.1.577.3110\&rep $=$ rep1\&type $=$ pdf $($ accessed March 30, 2010).

Tršelič Selan, A. 2006. Metodološke Značilnosti Ankete o Porabi Gospodinjstev v Sloveniji in Evropski Uniji. Ljubljana: Institute of Macroeconomic Analysis and Development of the Republic of Slovenia. Available at: http://www.umar.gov.si/ fileadmin/user_upload/publikacije/dz/2006/dz07-06.pdf. (accessed January 11, 2008).

UN. 2009. Practical Guide to Producing Consumer Price Indices. New York and Geneva: United Nations. Available at: http://www.unece.org/fileadmin/DAM/stats/publications/ Practical_Guide_to_Producing_CPI.pdf. (accessed May 23, 2014).

Vrabič Kek, B., M. Arnež, and P. Blažič. 2014. Standardno Poročilo o Kakovosti za Raziskovanje Poraba v Gospodinjstvih za Leto 2012. Ljubljana: Statistical Office of the Republic of Slovenia. Available at: http://www.stat.si/doc/metodologija/kakovost/ SPK_APG_2012.pdf. (accessed May 14, 2014).

World Bank. (2016). Statistical Capacity Building. Available at: http://www.worldbank. org/en/data/statistical-capacity-building/overview (accessed September 30, 2016).

Received May 19, 2014

Revised October 11, 2016

Accepted October 13, 2016 